\title{
Complementarity in the adoption of traceability of beef cattle in Brazil
}

\author{
Marcela de Mello Brandão Vinholis ${ }^{\mathrm{a} *}$, Hildo Meirelles de Souza Filho ${ }^{\mathrm{b}}$, Marcelo José Carrerc, \\ Waldomiro Barioni Juniora, Fabio Ribas Chaddadd,e \\ ${ }^{a}$ Empresa Brasileira de Pesquisa Agropecuária, São Carlos, SP, Brasil \\ bUniversidade Federal de São Carlos, São Carlos, SP, Brasil \\ 'Instituto Federal de Educação Ciência e Tecnologia, São Carlos, SP, Brasil \\ ¿University of Missouri, Columbia, MO, USA \\ eInsper, São Paulo, SP, Brasil \\ *marcela.vinholis@embrapa.br
}

\begin{abstract}
Complementarity is an interesting approach to explain technology adoption. Taking account the other activities the farm performs in its production strategy can help understanding the decision on the adoption of new agricultural technology. This paper aims to evidence the existence of synergic effect resulting from the joint adoption of feedlot and traceability certification of beef cattle in Brazil. A sample of 84 beef cattle farms provided data to test hypotheses by using an OLS regression model. A measure of performance - revenue - is regressed on variables representing both isolated and joint adoption of capital-intensive production system and traceability. The results suggest the existence of synergic effect when joint adoption takes place. Joint adoption is influenced by a set of management practices, such as forward contracts, training of employees and zootechnical performance control, which are shared by both capital-intensive production systems and traceability.
\end{abstract}

Keywords

Technology diffusion. Technology adoption. Agriculture. Capital-intensive production system.

\section{Introduction}

Beef cattle production in Brazil is marked by great diversity and technological heterogeneity between farms. While some farmers adopt capital-intensive production systems and have high yields per area and/or per animal, others adopt extensive systems with low technical efficiency (Zylbersztajn \& Machado Filho, 2003; Souza Filho et al., 2010). Such heterogeneity in beef cattle production in Brazil has been justified, historically, by the abundance of land and by the absence of economic and institutional pressures to increase yields. However, since the 1990s, the prices for arable land have increased along with a growing share of Brazilian beef exports in the international market (Brasil, 2014). In addition, many environmental restrictions were recently introduced in order to prevent deforestation for land use. Consequently, the diffusion of capital-intensive production systems with higher yields has increased among Brazilian beef cattle farmers.

The adoption of food safety standards and certifications, which includes traceability, has become a necessary condition to gain access to international markets. Food contamination cases and the BSE crisis in the 1990s highlighted the close interdependence between different stages of agrifood chains and the limitations of quality control along these chains (Matos \& Rossi, 2007; Hobbs, 2004). As a result, more stringent food safety and food quality regulations have been introduced by governments (Krieger $\&$ Schiefer, 2007; Fulponi, 2006; Trienekens \& Zuurbier, 2008).

The European Union (EU) has increased food safety standards for fresh beef imports, which 
creates challenges to large exporters, such as Brazil. More specifically, the EU has demanded traceability and has created a set of directives for their trade partners as conditions to gain access to its market (Regattieri et al., 2007). In order to comply with EU demands and sustain the trade partnership, Brazilian authorities had to adjust the country food safety regulation related to the beef industry. In 2002, the Brazilian System of Identification and Certification of Bovine and Bubaline Origin - SISBOV - was created as an official tool designed to ensure traceability in the beef chain. This system is of voluntary adoption, and is coordinated by the Ministry of Agriculture, Livestock and Food Supply. The ministry is also responsible for the accreditation of third party private certifiers. The SISBOV certification became a necessary condition for Brazilian producers to export to the EU. In addition, the farm must also be part of TRACES (Trade Control and Expert System) - a veterinary health network created by the EU, which notifies, certifies and monitors trade in animals and animal products.

A SISBOV certified farm must adopt traceability and a set of management practices and operational technologies. The implementation of traceability leads to the adoption of practices such as: individual identification of animals; records and documentation in order to track the history and movement of each animal; inventory control and the adoption of information technologies, such as software and electronic devices for cattle management (Cócaro \& Jesus, 2007; Carrer et al., 2014).

The adoption of these innovations at the farm level requires time, training of employees and capital investments. In return, exporting slaughterhouses pay a premium price for traced cattle. It should be noted that farmers who decide not to adopt SISBOV certification are still enabled to sell non-traced cattle to other markets, such as the domestic market and other countries. In August 2015, there were 1,628 certified farms in Brazil and only 122 certified farms in the State of São Paulo (Brasil, 2015). The certified farms in Brazil represent 0.5\% of the total of Brazilian farms with more than 50 bovines issued in the last Brazilian Agricultural Census (Instituto Brasileiro de Geografia e Estatística, 2006).

Thus, diffusion of the SISBOV certification was low, which suggests the premium price paid by processors was not a strong incentive for adoption. Which factors have led some farmers to adopt this certification and the associated technologies and management practices? The literature on technology adoption provides a framework to test hypotheses based on factors which may accelerate, slow down or even render the adoption unfeasible (Sunding \& Zilberman, 2001).
This approach is related to technological diffusion, in which exogenous determinants either foster or hinder the adoption. An alternative approach is based on the concept of complementarity developed by Milgrom \& Roberts (1990), in which the probability of adoption of an innovation increases when it is complementary to other technologies already adopted.

The concept of complementarity is an interesting approach to explain the slow and irregular process of technological diffusion (Bocquet et al., 2007; James Junior et al., 2011). However, this approach has been seldom explored in empirical studies on adoption of agricultural technology. This study fills this gap in the literature by examining the existence of complementarity between the adoption of capital-intensive production systems, such as feedlot, and the adoption of SISBOV traceability. Both strategies involve the adoption of a set of complementary management technologies and practices. It is hypothesized that the effect of complementarity on the economic performance of livestock production helps to explain the low adoption of traceability systems in Brazil. The complementarity hypothesis is investigated with survey data collected from a sample of 84 beef farmers in the State of São Paulo, Brazil.

This paper is organized as follows. The next section describes the theoretical and empirical literature on complementarity. Section 3 contextualizes the complementary variables and the factors that affect the synergic effect of complementarity in the beef supply chain. The productivity approach used to evidence the existence of complementarity is presented in section 4. Empirical results are discussed in section 5, while section 6 presents the conclusions.

\section{Theoretical approach}

The concept of complementarity was initially used by Milgrom \& Roberts (1990) to explain the revolution in the manufacturing industry carried out by the adoption of technologically advanced machinery and new forms of organization. The authors formalize the intuitive idea of synergy, i.e., the idea that the whole is greater than the sum of the parts (Milgrom \& Roberts, 1995). According to this approach, new technology is adopted in order to optimize the firm's strategy, as well as other organizational and technological practices (Bocquet et al., 2007).

Following this idea, Gómez \& Vargas (2012) state that some technologies should not be analyzed in isolation. On the contrary, the adoption of a given technology is better explained when one takes into account that it is part of a system alongside other technologies. Joint adoption helps the firm to build 
systems in which complementarity between the parts can arise. Complementarity exists when a change in one or more elements of the system leads to a change in another. Suppose the firm has already adopted three management practices (A, B, and C) that are complementary to a new management technology (D). This means that the probability of the new management technology (D) being adopted by the firm increases when the three management practices (A, B, and C) are present. This does not mean that the new management technology (D) cannot be adopted without the presence of the other three practices (A, B, and C) (James Junior et al., 2011). In general, the complementary elements of a system tend to move together systematically and consistently in response to contextual changes. Changes favoring the increase in one element of the system tend to also increase the occurrence of the others (Milgrom \& Roberts, 1995).

In order to adapt to contextual changes, the firm is more likely to achieve higher performance levels in new activities that are complementary to other previously established ones. Thus, one of the skills involved in this process of decision-making is to recognize synergies in new available technologies or complementarities with existing activities (Milgrom \& Roberts, 1995).

Previous studies on complementary technologies have provided empirical evidence on the existence of such complementarities between different technologies. Bocquet et al. (2007) found that the probability of information technology adoption is significantly and positively associated with the presence of other organizational practices. EDI adoption is complementary to an organizational design that combines tools to enhance employee incentives, formal contracts with customers and suppliers, and quality improvement procedures. Zhu (2004) provided evidence that superior performance (revenue generation, cost reduction, asset return and inventory turnover) of retail firms can arise from combining e-commerce capabilities with IT infrastructure. Aral et al. (2012) found evidence of complementarity between information technology, performance pay, and human resource analytics practices when these practices are implemented jointly rather than separately. Gómez \& Vargas (2009) provided evidence that the adoption of one of the technologies employed in manufacturing (numerically controlled machines, computer aided design and robotics) is positively related to the introduction of the other two.

Few empirical studies, however, show the existence of complementarity in the adoption of agricultural technologies. Huffman \& Mercier (1991) investigated the influence of the management complexity of different rural activities on the adoption of computers and computer services. The authors found that the greater the management complexity, such as in large livestock farms, the more likely the adoption of such technologies. They concluded that the adoption of computer and related services were complementary inputs to the complexity of rural activity management. Melo (2012) proposes a model of financial risk management for the feedlot activity in Brazil. In his model, the premium price for traced animals was very important in order to explain the economic viability of feedlot systems. This result suggests the existence of synergic effects between adoption of traceability and the feedlot system.

\section{Empirical hypothesis}

The beef cattle production system in Brazil is predominantly extensive in low-yield pastures. However, the adoption of more capital-intensive production systems has increased, mainly in the Southeast and Midwest. This production intensification process is associated with the rise in land prices, the competition with more profitable agricultural crops (Souza Filho et al., 2010) and societal pressures against beef cattle production in preservation areas and natural forests (lgreja et al., 2008). Beef cattle production has been considered one of the villains of deforestation and emission of greenhouse gases in Brazil. Such emissions are especially evident in areas with degraded pastures (Olivette et al., 2011). Although there is no consensus in the literature regarding the effects of production intensification on environmental problem mitigation, it has been considered an alternative, allowing for crop expansion without further deforestation (Bowman et al., 2012).

In Brazil, beef cattle production is fragmented into three phases: breeding, raising and fattening. The breeding phase comprises the period ranging from the birth of the calf up until weaning; the raising, from weaning up until the steer has reached $300 \mathrm{~kg}$ of weight, and the final phase ranges to up until slaughter. Farmers in the state of São Paulo tend to focus on the fattening phase due to the high price of land and the local demand from a large number of beef exporting slaughterhouses. In 2014, 51\% of total Brazilian beef export volume was shipped from ports in São Paulo state (Brasil, 2014). In addition, 740.000 bovines were fattened in feedlots of the state of São Paulo, which represented $17.6 \%$ of total slaughtered herds fattened in feedlots in Brazil (Bueno et al., 2015).

According to Cezar et al. (2005) feedlots use the highest technological intensity of any production system. The animals are confined during the finishing 
phase for a period ranging from 60 to 120 days, depending on the entry weight of the animals and the feedlot's level of technological intensification. The main objective of this system is to optimize animal weight gain in order to reduce the production cycle and increase yields, both per area and per animal.

The risk and complexity of capital-intensive production systems, such as feedlots, can be high. Contrasting with extensive production systems, intensive production in feedlots requires planning and strict production management, otherwise profitability is jeopardized (Correa et al., 2000). Thus, the adoption of capital-intensive production systems is associated with the adoption of a set of advanced management tools, such as inventory control, livestock performance control, production cost spreadsheets, training of employees and price hedging. In order to avoid price risks in the spot market, forward contracts are negotiated with the slaughterhouses, as well as price hedging contracts in future markets.

Similar to production intensification, Brazilian beef export growth has brought challenges related to food safety. The implementation of animal traceability along the beef supply chain is one of them. Some beef importers, mainly the EU, have demanded traceability as a condition for market access. This demand has had an impact on the national food safety regulation. In 2002, The Brazilian System of Identification and Certification of Bovine and Bubaline Origin (SISBOV) was created in order to meet the EU traceability requirements. This system, based on voluntary adoption, is coordinated by the Ministry of Agriculture, Livestock and Food Supply (MAPA). This tool has been adopted in order to keep records that allow for the tracing of beef origin along the supply chain. The traceable unit is the bovine animal, and its identification is unique nationwide. The information is centralized and stored in a National Data Base (BND), managed by the MAPA. The conformity of the traceability system is certified by the MAPA, which is responsible for the accreditation of private third-party certification agencies. The certified farm is inspected periodically and systematically by such agencies, under penalty of certification suspension. The compliance of these inspections is confirmed by a MAPA audit.

The implementation of traceability leads to the adoption of some practices, such as the individual identification of animals; the recording of the animal's history; inventory control and the adoption of information technologies, such as software and electronic devices for cattle management (Nantes \& Machado, 2005; Cócaro \& Jesus, 2007). The implementation of these technologies requires time, training of employees and acquisition of equipment, which means that significant investments are to be carried out by the farmer.

Both production intensification (in feedlot systems) and traceability certification by SISBOV require the adoption of a set of similar management practices and technologies, the training of employees as well as management skills. In addition, both are susceptible to economies of scale. The larger the scale of production, the lower the unit cost in feedlots (Lopes et al., 2007) and the lower the unit cost of traceability certification (Mendes, 2006; Lopes et al., 2008). Thus, the hypothesis of the existence of complementarity resulting from the joint adoption of intensive production systems and certification of cattle traceability is proposed.

\section{Research method}

The sample comprises cross-section data on 84 farms located in the livestock production region of the state of São Paulo, from which 16 had adopted feedlot as a long term strategy of fattening and 32 had SISBOV traceability certification. They were randomly selected from a list of farms, which in turn was obtained from records of farmers associations, rural unions and the list of farms approved to export beef to the EU. Interviews were carried out personally with the farm owners and had an average duration of two hours. All farms were visited between February and August 2011.

In several empirical studies, a measure of performance (such as productivity, revenue generation, cost reduction, return on assets, inventory turnover, customer satisfaction and quality) is regressed on complementary activities (information technology and e-commerce capability; internal R\&D and external knowledge acquisition; information technology, performance pay and human resources analytics practices; hospital levels of specialization and quality of clinical performance; organization practices and information technologies) in order to test for complementarity (Athey \& Stern, 1998; Zhu, 2004; Cassiman \& Veugelers, 2006; Aral et al., 2012; Clark \& Huckman, 2012; Tambe et al., 2012).

In this paper, an OLS multiple regression model was also used to test the synergic effect of complementarity. The response variable is the natural logarithm of the farm's livestock revenue in 2010 (see definition of variables in Table 1). The choice of revenue as the performance variable relies on the fact that certification of traceability allows the producer to capture a premium price, whereas the intensification of production allows for better quality carcasses. Both strategies can positively affect cattle 
Table 1. Definition of variables used in the OLS model and in the logit models.

OLS model

\begin{tabular}{|c|c|}
\hline \multicolumn{2}{|l|}{ Dependent variable } \\
\hline LnRevenue & $\begin{array}{l}\text { Natural logarithm of the farm's livestock revenue. The revenue is determined by the quantity of cattle } \\
\text { sold in } 2010 \text { multiplied by the cattle price in } 2010 \text {. }\end{array}$ \\
\hline \multicolumn{2}{|l|}{ Explanatory variables } \\
\hline Size & Total area of pasture in hectares \\
\hline Associations & $\begin{array}{l}\text { If farmer attends meetings of farmers' associations both formally and informally organized }=1 \text {, } \\
\text { otherwise }=0 \text {. }\end{array}$ \\
\hline Schooling & Number of years of the farmer's schooling \\
\hline NoTraceability\& Feedlot & $\begin{array}{l}\text { Neither feedlot as long term strategy of fattening nor certification of traceability is adopted }=1 \text {, } \\
\text { otherwise }=0\end{array}$ \\
\hline FeedlotOnly & $\begin{array}{l}\text { Adoption of feedlot as long term strategy of fattening and non-adoption of traceability and its } \\
\text { certification }=1 \text {, otherwise }=0\end{array}$ \\
\hline TraceabilityOnly & $\begin{array}{l}\text { Adoption of traceability and its certification and non-adoption of feedlot as long term strategy of } \\
\text { fattening }=1 \text {, otherwise }=0\end{array}$ \\
\hline Traceability\& Feedlot & $\begin{array}{l}\text { Joint adoption of feedlot as long term strategy of fattening and certification of traceability }=1 \text {, } \\
\text { otherwise }=0\end{array}$ \\
\hline \multicolumn{2}{|r|}{ Logit models } \\
\hline \multicolumn{2}{|l|}{ Dependent variables } \\
\hline Forward contract & Farmers who adopted forward contract with slaughterhouse $=1$, otherwise $=0$ \\
\hline Training of employees & Farmers who train employees for production techniques or management practices $=1$, otherwise $=0$ \\
\hline $\begin{array}{l}\text { Zootechnical performance } \\
\text { control }\end{array}$ & $\begin{array}{l}\text { Farmers who keep records to control the production system and to monitor zootechnical performance }=1 \text {, } \\
\text { otherwise }=0\end{array}$ \\
\hline \multicolumn{2}{|l|}{ Explanatory variables } \\
\hline Size & Total area of pasture in hectares \\
\hline Feedlot & Adoption of feedlot as long term strategy of fattening $=1$, otherwise $=0$ \\
\hline Traceability & Adoption of traceability and its certification $=1$, otherwise $=0$ \\
\hline Traceability\& Feedlot & $\begin{array}{l}\text { Joint adoption of feedlot as long term strategy of fattening and certification of traceability }=1 \text {, } \\
\text { otherwise }=0\end{array}$ \\
\hline
\end{tabular}

Source: elaborated by the authors.

price, which in turn influences revenue. The total area of pasture utilized by the farmer is used to control for size.

The existence of the synergic effect between simultaneous adoption of feedlot and traceability certification is examined in the model by introducing four independent binomial variables to represent (see Table 1): (i) exclusive adoption of traceability certification (TraceabilityOnly), (ii) exclusive adoption of feedlot (FeedlotOnly), (iii) non-adoption of both traceability certification and feedlot (NoTraceability\& Feedlot), and (iv) simultaneous adoption of traceability certification and feedlot (Traceability\& Feedlot). The latter captures the synergic effect of joint adoption. A positive effect on farm revenue, which is the response variable, is expected. The greater the impact of the joint adoption compared to the effect of isolated adoption, the greater the effect of complementarity.

In addition to these four variables, the model also comprises three control variables to account for the effects of human capital (farmer schooling - Schooling), access to information (attendance to meetings of farmers' associations both formally and informally organized - Associations) and scale (hectares of pasture - Size) on the response variable. The multiple regression model is specified as follows:
LnRevenue $=\beta_{1}$ Size $+\beta_{2}$ Associations $+\beta_{3}$ Schooling +

$\theta_{00}$ NoCertification \& Feedlot $+\theta_{01}$ FeedlotOnly +

$\theta_{10}$ TraceabilityOnly $+\theta_{11}$ Traceability \& Feedlot $+u$

where $\theta_{\mathrm{kl}}$ are the coefficients on the farmers' strategy choice, and $\beta_{i}$ are the coefficients of control variables affecting revenue.

Following Brynjolfsson \& Milgrom (2013) and Cassiman \& Veugelers (2006), the test for complementary between traceability certification and feedlot is:

$\theta_{11}-\theta_{10} \geq \theta_{01}-\theta_{00}$

In order to ease the interpretation of the coefficients, all the exclusive dummy variables were included in the regression, but they do not include a constant term. The analyses were performed using $\mathrm{SAS}^{\circledR}$ software. The direct test for complementarity was performed using the following statement:

proc reg data=DATA-SET;

model y = x1-XP C00 C01 C10 C11/noint;

TEST COMPLEMENTARITY: TEST C11-C01-C10+C00/ PRINT;

RUN;

Adopting traceability certification when feedlot is already adopted will result in higher incremental 
revenue than when adopting traceability certification and feedlot in isolation. If the performance difference is significantly greater than zero, the null hypothesis of no complementarity can be rejected. This test aims to show whether the benefits of implementing both activities jointly are greater or not than the sum of the benefits of each activity in isolation. It is expected that farmers who jointly adopt capital-intensive production systems, such as feedlot and traceability certification, have greater returns than farmers implementing these strategies separately.

After testing for the existence of complementarity, it is possible to identify factors that can explain the joint occurrence of feedlot and traceability certification. This additional analysis helps to understand in which conditions complementarity takes place (Cassiman \& Veugelers, 2006). Both feedlot and traceability certification require a set of common management practices and technologies, as explained in section 3. As the adoption of this set has fixed costs, a joint adoption reduces unit cost.

In order to test the role played by joint adoption of feedlot and traceability certification on the adoption of common management practices, six binomial logit models were estimated. Two models were estimated for each dependent variable. The first comprises the non-exclusive variables (Feedlot and Traceability) and the second comprises the joint adoption variable (Feedlot\& Traceability). This procedure was performed because of the existence of linear combination among these variables. Additionally, Size was included in both models as a control variable. A positive and significant effect of joint adoption on the adoption of management practices would confirm and explain the decision on the adoption of complementary strategies. The definitions of the variables used in these models are in Table 1. The binomial logit models are specified as follows:

$\operatorname{Pr}\left(y_{i}=1\right)=\frac{e^{\beta X}}{1+e^{\beta X}}=\Lambda\left(\beta^{\prime} X\right)$ where X denotes a set of explanatory variables (Size, Feedlot, Traceability, and Traceability\& Feedlot). The observed pattern of adoption can be described by a dummy variable, $y$, such that $y i=1$ if producer $i$ adopts the management practices (Forward contract, Training of employees, and Zootechnical performance control) and $\mathrm{yi}=0$ if he does not. $\Lambda$ denotes the logistic cumulative distribution function.

\section{Results and discussion}

The association between feedlot adoption and traceability certification adoption was initially examined via Spearman correlation. As expected, both strategies are positively correlated $(0.43$, significant at the $1 \%$ level), which is consistent with complementarity. If feedlot and traceability are complementary, the synergic effect should also be apparent in farm performance.

A joint test for the equality of weighted means of the four exclusive combinations of feedlot and traceability adoption was also performed (Table 2). The means were weighted by the inverse of the number of observations because the number of observations was unbalanced among the exclusive variables. If the weights for the observations are proportional to the reciprocals of the error variances, then the weighted least squares estimates are the best linear unbiased estimators. The equality of means was rejected with a $p$-value of 0.0107 . A one-sided test of non-complementarity is rejected at the $5 \%$ level of significance, providing additional evidence for the possibility of complementarity between feedlot and traceability.

The OLS regression of LnRevenue on the control variables and the exclusive variables was then carried out. The results are presented in Table 3. The $p$-value of the test for the general significance of the estimated regression, that is, the $F$ statistic, was low enough to reject the hypothesis that all the regression coefficients are equal to zero. The adjusted $R^{2}$ of the estimated regression is 0.99 .

Table 2. Frequency and financial performance by combinations of complementary activities: feedlot and traceability.

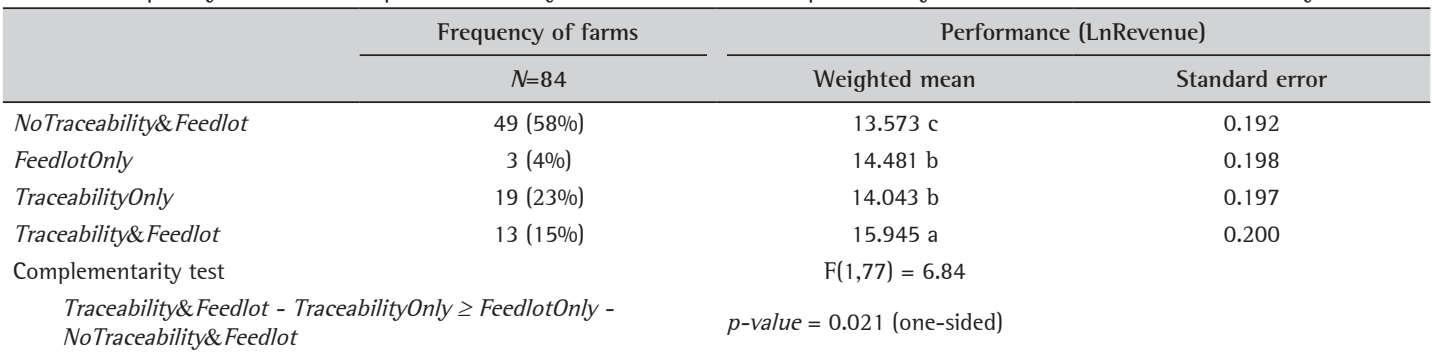

Note. Schooling, Associations and Size were included as covariates. Source: elaborated by the authors. 
The residuals of the model follow a normal distribution, as shown in Figure 1. The points are close to the identity line. Also, the KolmogorovSmirnov and Shapiro Wilk tests satisfy the normality assumption. The $p$-value of both tests is greater than 0.05 (Table 3). The residuals also meet the assumption of constant variance (homoscedasticity) as shown in Figure 1. There is no evidence of a systematic pattern between residual and predicted values.

All estimated coefficients in the regression are significant at 5\% significance level or lower, with the exception of schooling (less than 10\%). Both dummy variables FeedlotOnly and TraceabilityOnly have positive impact on farm revenue, but the coefficients are lower than the joint adoption represented by Traceability\& Feedlot. The direct test of performance differences for complementarity $\left(\theta_{11}-\theta_{10} \geq \theta_{01}-\theta_{00}\right)$ is accepted at the $10 \%$ level of significance $(p$-value $=0.0772)$. The result suggests that farms achieve greater benefits from traceability certification when it is adopted in association with the feedlot production system. The result corroborates other studies that tested the role of complementarity in both business and technology adoption. Zhu (2004) also found that complementarity has a positive effect on firm revenue. Monteiro \& Caswell (2009) argued that traceability indirectly affects farm revenue because it is a quality attribute of product. Feedlot production provides better quality for carcasses, which in turn positively affects revenue. The joint adoption of feedlot and traceability was more effective in improving revenue than when adopted separately.

Table 3. Results of the multiple regression model and the complementarity test for evidencing the joint adoption of feedlot and traceability.

\begin{tabular}{|c|c|c|c|c|}
\hline & Parameter estimate & Standard error & t Value & $\operatorname{Pr}>|t|$ \\
\hline Size & 0.5458 & 0.0559 & 9.77 & $<0001$ \\
\hline Schooling & 0.0616 & 0.0352 & 1.75 & 0.0842 \\
\hline Associations & 0.6373 & 0.2779 & 2.29 & 0.0245 \\
\hline NoTraceability\& Feedlot & 8.8848 & 0.5811 & 15.29 & $<0001$ \\
\hline FeedlotOnly & 9.8097 & 0.7808 & 12.56 & $<0001$ \\
\hline TraceabilityOnly & 9.2828 & 0.6621 & 14.02 & $<0001$ \\
\hline Traceability\& Feedlot & 11.1825 & 0.6856 & 16.31 & $<0001$ \\
\hline \multicolumn{5}{|l|}{ Complementarity test } \\
\hline$\left(\theta_{11}-\theta_{10} \geq \theta_{01}-\theta_{00}\right)$ & $\begin{array}{c}\mathrm{F}(1,77)=3.21 \\
N=84\end{array}$ & $\operatorname{Pr}>\mathrm{F}$ & 0.0772 & \\
\hline \multicolumn{5}{|l|}{ Model } \\
\hline Adj R-Sq & 0.997 & & & \\
\hline $\mathrm{F}(7,77)$ & 3965.23 & $\operatorname{Pr}>\mathrm{F}$ & $<.0001$ & \\
\hline Shapiro-Wilk (W) & 0.980102 & $\mathrm{PR}<\mathrm{W}$ & 0.2198 & \\
\hline Kolmogorov-Smirnov (D) & 0.058556 & $\mathrm{PR}>\mathrm{D}$ & $>0.1500$ & \\
\hline
\end{tabular}

Source: elaborated by the authors.

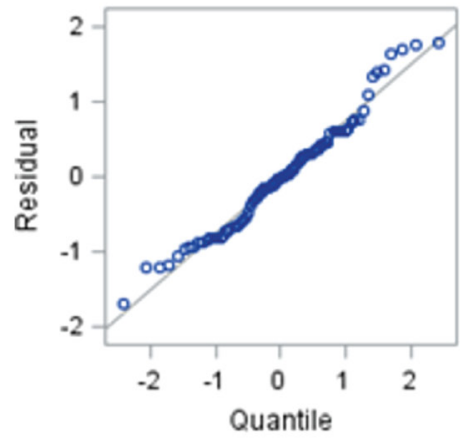

a. Normal probabilistic plot of regression residues.

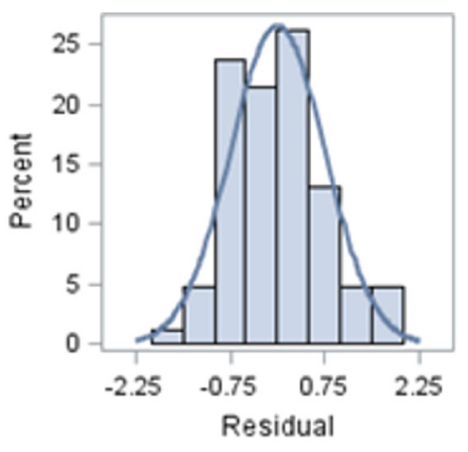

b. Histogram of residuals.

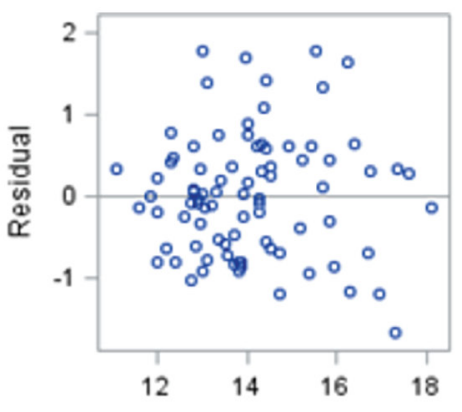

\section{c. Predicted vs. residual values of regression.}

Figure 1. Residual analysis of the multiple regression model performed to test for complementarity. Source: elaborated by the authors. 
Size of pasture, level of schooling and association are important variables controlling for the impact of farm and farmer characteristics on revenue. These three results can be explained as follows. First, farmers with large production scales may have greater bargaining power to get better sale prices, as suggested by Baer \& Brown (2007), which positively affects revenue. Second, the active participation in formal and informal associations facilitates access to important market information and increases the bargaining power for marketing finished cattle in producer pools, as suggested by Monteiro \& Caswell (2009). Third, higher level of schooling enable greater capacity for interpretation and use of information, as well as better conditions for price negotiation and adoption of new production techniques, which can also affect revenue. Huffman \& Mercier (1991) concluded that farmers' schooling is a relevant variable explaining the joint adoption of computer technology and purchased computer services. In order to identify factors that can explain the farmer's decision regarding joint adoption of Traceability and Feedlot, six logit regression models were performed for the adoption of three management tools in 2010: forward contract, training of employees and zootechnical performance control. The results are presented in Table 4.

The likelihood ratio was used to test the hypothesis that all the slope coefficients in the logit models are equal to zero. The chi-square results are significant at least at the 10\% significance level. With 2 and 3 degrees of freedom, the critical value at the 5\% significance level is 5.99 and 7.81 , respectively. And so, the joint hypothesis that the coefficients on the full set of variables are all zero is rejected for all adopted models.

The result suggests that the adoption of Feedlot has significant impact on the probability that farmers adopt forward contract with slaughterhouses. In fact, high capital-intensive livestock production systems require specific investments in facilities and human resources. Also, in feedlots, cattle must be sold exactly at the end of the production cycle, due to the high cost of feeding; delays are rarely accepted, otherwise profit could plummet. In order to mitigate the uncertainty and price risk associated with these specific investments, these farmers adopt forward contracts, as suggested by Vinholis et al. (2014). If they decide to adopt traceability certification, they can negotiate for the inclusion of premium price in the contracts, so that the appropriation of the returns of traceability investments is ensured. The probability of adoption of forward contracts significantly increases when farmers raise cattle by means of the feedlot system and adopt traceability (Traceability\& Feedlot). The certification of traceability also requires investments in training and information technology equipment; however, its adoption in isolation is not sufficient to foster the adoption of forward contracts. This is the case of farmers who adopt less intensive production systems, in which cattle can be kept grazing for longer due to lower feeding cost. Thus, these farmers can wait longer if they expect prices to improve in the spot market, choosing the latter over signing forward contracts.

The adoption of Feedlot implies stricter production management controls, which requires skilled labor. However, the adoption of Feedlot in isolation was not statistically significant to determine the training of employees. A possible explanation is the lack of data for training before 2010. In fact, most feedlot adopters were not training employees in 2010 because they had done it previously; while adopters of traceability were training employees in 2010 because traceability is a more recent strategy than feedlot. The parameters of Traceability in isolation and jointly with feedlot

Table 4. Results of the Logit regressions (odds ratio) performed to identify factors influencing the joint adoption of feedlot and traceability.

\begin{tabular}{|c|c|c|c|c|c|c|}
\hline \multirow[b]{2}{*}{ Intercept } & \multicolumn{2}{|c|}{ Forward contract } & \multicolumn{2}{|c|}{ Training of employees } & \multicolumn{2}{|c|}{ Zootechnical performance control } \\
\hline & 0.1372 & 0.1430 & 1.3686 & 0.8803 & 8.0186 & 3.3612 \\
\hline & $(1.3776)$ & (1.3297) & $(1.1220)$ & $(1.0715)$ & (1.2983) & (1.1792) \\
\hline \multirow[t]{2}{*}{ Feedlot } & $4.1918^{* * *}$ & & 1.6150 & & $2.4829^{*}$ & \\
\hline & $(0.3935)$ & & $(0.3710)$ & & (0.5524) & \\
\hline \multirow[t]{2}{*}{ Traceability } & 1.1525 & & $1.7076^{*}$ & & $1.7653^{*}$ & \\
\hline & $(0.3341)$ & & $(0.2773)$ & & $(0.3128)$ & \\
\hline \multirow[t]{2}{*}{ Traceability\& Feedlot } & & $4.6100^{* * *}$ & & $2.2374^{* * *}$ & & $2.6612^{*}$ \\
\hline & & $(0.4221)$ & & $(0.4074)$ & & $(0.5395)$ \\
\hline \multirow[t]{2}{*}{ Size } & 1.3073 & 1.3367 & 1.0546 & 1.1472 & 0.9306 & 1.0395 \\
\hline & $(0.1913)$ & $(0.1798)$ & $(0.1532)$ & $(0.1427)$ & $(0.1654)$ & $(0.1492)$ \\
\hline \multicolumn{7}{|l|}{ Model } \\
\hline \multicolumn{7}{|l|}{$N=84$} \\
\hline $\mathrm{X}^{2}$ & $27.68^{* * * *}$ & $24.44^{* * *}$ & $10.85^{* *}$ & $7.05^{* *}$ & $11.70^{* * * *}$ & $5.63^{*}$ \\
\hline
\end{tabular}

Notes. Significant at $1 \%^{* * *} ; 5 \%{ }^{* * *} ; 10 \%$. Standard errors are in parentheses. Source: elaborated by the authors. 
(Traceability\& Feedlot) are positive and statistically significant at the $10 \%$ and $5 \%$ level, respectively, on the training of employees. The adoption of both Feedlot and Traceability, either in isolation or simultaneously (Traceability\& Feedlot), has a positive and statistically significant effect at the 10\% level on the adoption of zootechnical performance controls. Management practices and skills required for traceability adoption are close to those required for the feedlot system. Intensification increases the risk and complexity of the production system, since the cost structure is altered and requires significant investments for the adoption of the required technological package. This situation requires stricter production, cost and inventory controls, without which the profitability of the system would be jeopardized (Correa et al., 2000).

In summary, the adoption of intensive production systems requires the adoption of a set of management tools, such as marketing contracts, employee training and management controls. Farmers who are already adopters of these tools are more likely to adopt traceability and its certification.

This result corroborates James Junior et al. (2011) who claim that organizational practices in the agrifood sector might be characterized by complementarities with few decomposable parts of a system. As a constituent element of a system, the adoption of one of these practices, which is an element itself, is facilitated when the firm had already adopted other. It happens because the new practice fits well and optimizes other choices of the firm, namely, the other elements of the bundle of complementary elements. Consequently, the firm performance is higher, as suggested by Milgrom \& Roberts $(1990,1995)$ and Bocquet et al. (2007).

The real need for complementary practices can explain the slow and uneven diffusion of a technology. This implies that an exogenous change in demand or regulation can change the path of diffusion. For instance, traceability certification (SISBOV) in Brazil became compulsory for beef exports to European Union, although it is voluntary for internal market. In the institutional environment, firms can adopt different behaviors (James Junior et al., 2011). Here, the coexistence of feedlot and the set of management tools fosters the adoption of traceability in order to take the advantages of the European Union's market. However, farmers adopting non-intensive systems would not take the same decision. The net benefits are higher in the jointly adoption than in separately. Figure 2 illustrates the complementarities in the adoption of traceability of beef cattle. In addition to the technology diffusion view, this result helps explaining its low adoption in Brazil.

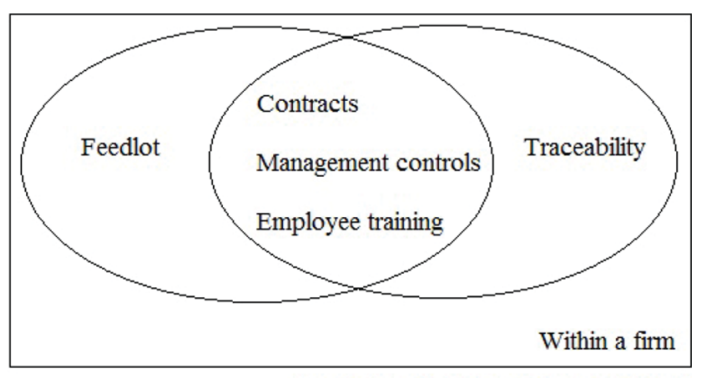

Regulatory design (exogenous factor)

Figure 2. Bundle of complementary practices. Source: elaborated by the authors.

The result also fills a gap in the literature. James Junior et al. (2011) underline the research on complementarities is young and has not been applied systematically to the agrifood sector. The authors also state the potential for innovative research is great since the list of significant and specific variables to particular sector may be long. By providing empirical evidence on the adoption of traceability at farm level, this research enlarges the list of studies identifying technological complementarities within the agrifood sector and innovates by presenting complementary variables within the livestock production.

\section{Conclusions}

The adoption of more intensive beef cattle production systems, such as feedlot, has increased in Brazil due to the rise in arable land price as well as more stringent environmental requirements. Simultaneously, challenges related to food safety, such as bovine traceability, are in the agenda in order to maintain and gain access to more demanding markets. This paper discussed and showed the synergic effect between the adoption of feedlot and traceability. The adoption of intensive production systems is associated with the adoption of a set of management technologies, such as controls for livestock performance and risk management tools. This technological package shows a synergic effect with the requirements for the adoption of bovine traceability and its certification. The latter requires identification of each animal in the herd, as well as inventory control and training of employees. Moreover, both strategies are susceptible to economies of scale. This synergy fosters and facilitates the adoption of bovine traceability and its certification.

The literature on the complementarity approach encourages studies aiming the identification of complementarities within the agrifood sector (James Junior et al., 2011). This paper provides empirical evidence for the existence of complementarity in the 
adoption of technologies in the livestock production. It provides indications regarding the barriers to the adoption of innovations that are economically viable only in conditions of complementarity with other innovations. Adoption in isolation does not generate the same performance as joint adoption. This result can be useful for policies which aim to provide incentives for the diffusion of innovation in agriculture.

\section{References}

Aral, S., Brynjolfsson, E., \& Wu, L. (2012). Three-way complementarities: performance pay, human resource analytics, and information technology. Management Science, 58(5), 913-931. http://dx.doi.org/10.1287/mnsc.1110.1460

Athey, S., \& Stern, S. (1998). An empirical framework for testing theories about complementarity in organizational design (Working paper, no. 6600). Cambridge: National Bureau of Economic Research. http://dx.doi.org/10.3386/w6600

Baer, A. G., \& Brown, C. (2007). Adoption of e-marketing by direct-market farms in the Northeastern United States. Journal of Food Distribution Research, 38(2), 1-11. Retrieved in 28 April 2015, from http://purl.umn.edu/43492

Bocquet, R., Brossard, 0., \& Sabatier, M. (2007). Complementarities in organizational design and the diffusion of information technologies: an empirical analysis. Research Policy, 36(3), 367-386. http://dx.doi.org/10.1016/j.respol.2006.12.005.

Bowman, M. S., Soares-Filho, B. S., Merry, F. D., Nepstad, D. C., Rodrigues, H., \& Almeida, O. T. (2012). Persistence of cattle ranching in the Brazilian Amazon: a spatial analysis of the rationale for beef production. Land Use Policy, 29(3), 558568. http://dx.doi.org/10.1016/j.landusepol.2011.09.009.

Brasil, Ministério da Agricultura, Pecuária e Abastecimento. (2015). SISBOV: Brazilian service of supply chain traceability of cattle and buffaloes. Brasília: MAPA. Retrieved in 28 August 2015, from http://www.agricultura.gov.br/animal/ rastreabilidade/sisbov

Brasil, Ministério do Desenvolvimento, Indústria e Comércio Exterior. (2014). Foreign trade statistics. Brasília: MDIC. Retrieved in 28 August 2015, from http://aliceweb.mdic. gov.br/

Brynjolfsson, E., \& Milgrom, P. (2013). Complementarity in organizations. In R. Gibbons \& J. Roberts (Eds.), The handbook of organizational economics (pp.11-55). Princeton: Princeton University Press.

Bueno, C. R. F., Martins, V. A., \& Caser, D. V. (2015). Efetivo de bovinos, suinos, frango de corte e galinhas de postura no estado de São Paulo, 2005 a 2014. Análises e Indicadores do Agronegócio, 10(4), 1-7. Retrieved in 28 August 2015, from http://www.iea.sp.gov.br/out/LerTexto.php?codTexto=13656

Carrer, M. J, Souza Filho, H. M., \& Vinholis, M. M. B. (2014). Plural forms of governance in the beef industry: a case study in Brazil. British Food Journal, 116(4), 643-661. http://dx.doi.org/10.1108/BFJ-04-2012-0089

Cassiman, B., \& Veugelers, R. (2006). In search of complementarity in innovation strategy: internal R\&D and external knowledge acquisition. Management Science, 52(1), 68-82. http:// dx.doi.org/10.1287/mnsc. 1050.0470

Cezar, I. M., Queiroz, H. P., Thiago, L. R. L. S., Garagorry, F. L., \& Costa, F. P. (2005). Sistemas de produção de gado de corte no Brasil: uma descrição com ênfase no regime alimentar e no abate. Campo Grande: Embrapa Gado de
Corte. Retrieved in 28 August 2015, from https://www. embrapa.br/gado-de-corte/busca-de-publicacoes/-/ publicacao/326307/sistemas-de-producao-de-gado-decorte-no-brasil-uma-descricao-com-enfase-no-regimealimentar-e-no-abate

Clark, J. R., \& Huckman, R. S. (2012). Broadening focus: spillovers, complementarities, and specialization in the hospital industry. Management Science, 58(4), 708-722. http://dx.doi.org/10.1287/mnsc. 1110.1448

Cócaro, H., \& Jesus, J. C. S. (2007). Impactos da implantação da rastreabilidade bovina em empresas rurais informatizadas: estudos de caso. Journal of Information Systems and Technology Management, 4(3), 353-374. Retrieved in 28 August 2015, from http://www.scielo.br/scielo. php?script=sci_arttext\&pid=S1807-17752007000300006\&ln $\mathrm{g}=\mathrm{pt} \& \mathrm{nrm}=\mathrm{iso}$

Correa, E. S., Vieira, A., Costa, F. P., \& Cezar, l. V. (2000). Sistema semi-intensivo de produção de carne de bovinos nelores no centro-oeste do Brasil. Campo Grande: Embrapa Gado de Corte. Retrieved in 28 August 2015, from https:// www.embrapa.br/gado-de-corte/busca-de-publicacoes/-/ publicacao/324073/sistema-semi-intensivo-de-producaode-carne-de-bovinos-nelore-no-centro-oeste-do-brasil

Fulponi, L. (2006). Private voluntary standards in the food system: the perspective of major food retailers in OECD countries. Food Policy, 31(1), 1-13. http://dx.doi.org/10.1016/j. foodpol.2005.06.006.

Gómez, J., \& Vargas, P. (2009). The effect of financial constraints, absorptive capacity and complementarities on the adoption of multiple process technologies. Research Policy, 38(1), 106-119. http://dx.doi.org/10.1016/j.respol.2008.10.013.

Gómez, J., \& Vargas, P. (2012). Intangible resources and technology adoption in manufacturing firms. Research Policy, 41(9), 1607-1619. http://dx.doi.org/10.1016/j. respol.2012.04.016

Hobbs, J. E. (2004). Information asymmetry and the role of traceability systems. Agribusiness, 20(4), 397-415. http:// dx.doi.org/10.1002/agr.20020.

Huffman, W. E., \& Mercier, S. (1991). Joint adoption of microcomputer technologies: an analysis of farmers' decisions. The Review of Economics and Statistics, 73(3), 541-546. http://dx.doi.org/10.2307/2109583.

Igreja, A. C. M., Martins, S. S., Rocha, M. B., Bliska, F. M. M., \& Tirado, G. (2008). Fatores locacional e tecnológico na competição cana versus pecuária para as regiões geográficas brasileiras. Revista de Economia Agrícola, 55(2), 89-103.

Instituto Brasileiro de Geografia e Estatística. (2006). Census of agriculture 2006. Rio de Janeiro: IBGE. Retrieved in 28 October 2010, from http://www.sidra.ibge.gov.br/bda/ acervo/acervo2.asp? $\mathrm{e}=\mathrm{v} \& \mathrm{p}=\mathrm{CA} \& \mathrm{Z}=\mathrm{t} \& 0=11$

James Junior, H. S., Klein, P. G., \& Sykuta, M. E. (2011). The adoption, diffusion, and evolution of organizational form: insights from the agrifood sector. Managerial and Decision Economics, 32(4), 243-259. http://dx.doi.org/10.1002/ mde. 1531 .

Krieger, S., \& Schiefer, G. (2007). Conception of integrated models for quality management in production chains in the agri-food sector. In L. Theuvsen, A. Spiller, M. Peupert \& G. Jahn (Eds.), Quality management in food chains (pp. 303-313). Wageningen: Academic Publishers.

Lopes, M. A., Santos, G., \& Amado, G. B. (2008). Viabilidade econômica da adoção e implantação da rastreabilidade em sistemas de produção de bovinos no estado de Minas 
Gerais. Ciência e Agrotecnologia, 32(1), 288-294. http:// dx.doi.org/10.1590/S1413-70542008000100041

Lopes, M. A., Santos, G., Magalhães, G. P., \& Carvalho, F. M. (2007). Efeito da escala de produção na rentabilidade da terminação de bovinos de corte em confinamento. Ciência e Agrotecnologia, 31(1), 212-217. http://dx.doi. org/10.1590/S1413-70542007000100031

Matos, C. A., \& Rossi, C. A. V. (2007). Consumer reaction to product recalls: factors influencing product judgement and behavioural intentions. International Journal of Consumer Studies, 31(1), 109-116. http://dx.doi.org/10.1111/j.14706431.2006.00499.x.

Melo, A. J. N. (2012). Confinamento: gestão de riscos com controles internos. Piracicaba: BeefPoint. Retrieved in 28 January 2013, from http://www.beefpoint.com.br/ radares-tecnicos/gerenciamento/confinamento-gestaode-riscos-com-controles-internos/

Mendes, R. E. (2006). 0 impacto financeiro da rastreabilidade em sistemas de produção de bovinos no estado de Santa Catarina, Brasil. Ciência Rural, 36(5), 1524-1528. http:// dx.doi.org/10.1590/S0103-84782006000500028

Milgrom, P., \& Roberts, J. (1990). The economics of modern manufacturing: technology, strategy, and organization. The American Economic Review, 80(3), 511-528. Retrieved in 28 January 2013, from http://www.jstor.org/stable/2006681

Milgrom, P., \& Roberts, J. (1995). Complementarities and fit strategy, structure and, organizational change in manufacturing. Journal of Accounting and Economics, 19(2), 179-208. http://dx.doi.org/10.1016/0165-4101(94)00382-F.

Monteiro, D. M. S., \& Caswell, J. A. (2009). Traceability adoption at the farm level: An empirical analysis of the Portuguese pear industry. Food Policy, 34(1), 94-101. http://dx.doi. org/10.1016/j.foodpol.2008.07.003.

Nantes, J. F. D., \& Machado, J. G. C. F. (2005). Segurança dos alimentos e rastreabilidade: o caso da carne bovina no Brasil. In M. 0. Batalha (Ed.), Gestão do agronegócio: textos selecionados (pp. 369-423). São Carlos: EdUFSCar.

Olivette, M. P. A., Castanho Filho, E. P., Sachs, R. C. C., Nachiluk, K., Martins, R., Camargo, F. P., Angelo, J. A., \& Oliveira, L. H. D. C. L. (2011). Evolução e prospecção da agricultura paulista: liberação da área de pastagem para o cultivo da cana-de-açúcar, eucalipto, seringueira e reflexos na pecuária, 1996-2030. Informações Econômicas, 41(3), 37-67.

Regattieri, A., Gamberi, M., \& Manzini, R. (2007). Traceability of food products: general framework and experimental evidence. Journal of Food Engineering, 81(2), 347-356. http://dx.doi.org/10.1016/j.jfoodeng.2006.10.032.

Souza Filho, H. M., Rosa, F. T., \& Vinholis, M. M. B. (2010). Análise da competitividade da cadeia produtiva da carne bovina do Estado de São Paulo. Informações Econômicas, 40(3), 16-28. Retrieved in 28 January 2013, from http:// www.iea.sp.gov.br/out/LerTexto.php?codTexto $=11867$

Sunding, D., \& Zilberman, D. (2001). The agricultural innovation process: research and technology adoption in a changing agricultural sector. In B. Gardner \& G. C. Rausser (Eds.), Handbook of Agricultural Economics (pp. 207-261). Amsterdam: Elsevier.

Tambe, P., Hitt, L. M., \& Brynjolfsson, E. (2012). The extroverted firm: how external information practices affect innovation and productivity. Management Science, 58(5), 843-859. http://dx.doi.org/10.1287/mnsc. 1110.1446

Trienekens, J., \& Zuurbier, P. (2008). Quality and safety standards in the food industry, developments and challenges. International Journal of Production Economics, 113(1), 107-122. http://dx.doi.org/10.1016/j.jpe.2007.02.050.

Vinholis, M. M. B., Souza Filho, H. M., Carrer, M. J., \& Chaddad, F. R. (2014). Transaction attributes and adoption of hybrid governance in the Brazilian cattle market. Journal on Chain and Network Science, 14(3), 189-199. http://dx.doi. org/10.3920/JCNS2014.0239.

Zhu, K. (2004). The complementarity of information technology infrastructure and e-commerce capability: a resource-based assessment of their business value. Journal of Management Information Systems, 21(1), 167-202. http://dx.doi.org/1 $0.1080 / 07421222.2004 .11045794$.

Zylbersztajn, D., \& Machado Filho, C. P. (2003). Competitiveness of meat agri-food chain in Brazil. Supply Chain Management: an International Journal, 8(2), 155-165. http://dx.doi. org/10.1108/13598540310468751 